early stages of otospongiosis, and subsequently maintained, by the viruses.

A prospective study of children notified to the national congenital rubella syndrome surveillance programme to determine how many develop otosclerosis in later life might be worth while.

I FRIEDMANN

Middlesex HA7 3NR

Kanpom Hospital

Switzerland

1 Wild NJ, Sheppard S, Smithells RW, Holzel H, Jones G Delayed detection of congenital hearing loss in high risk Delayed detection of congenital hearing

2 Friedmann I. The pathology of the ear. Oxford: Blackwell, 1974.

3 Arnold W, Friedmann I. Otosclerosis - an inflammator disease of the otic capsule of viral aetiology. $\mathcal{F}$ Laryngol Otol 1988;102:865-71.

McKenna MJ, Mills GB, Galey FR, Linthicum FH. Filamentous structures morphologically similar to viral nucleocapsids in otosclerotic lesions in two patients. Am $\mathcal{f}$ Otolaryngol 1986;71:25-8

\section{Treatment of viral pharyngitis or flu}

SIR, - Dr Linda Beeley suggests that a combination of aspirin and paracetamol might be useful in the treatment of viral pharyngitis or influenza.'

It was most unfortunate that her response to the questioner made no reference to the fact that aspirin is specifically contraindicated for this purpose in children because of the risk of developing Reye's syndrome. ${ }^{23}$ Indeed, some evidence suggests that Reye's syndrome in adults may also be associated with aspirin used to treat influenza. ${ }^{+}$

SUSAN M HALL

Communicable Disease Surveillance Centre,

London NW9 5EQ

1 Beeley L. Any Questions. BMF 1990;301:544. (15 September.)

2 Anonymous. Reye's syndrome and aspirin. BMF 1986;292:1590. 3 Hall SM, Plaster PA, Glasgow JFT, Hancock P. Preadmissio antipyretics in Reye's syndrome. Arch Dis Child 1988;63: $857-66$.

4 Meythaler JM, Varma RR. Reyes syndrome in adults: diagnostic considerations. Arch Intern Med 1987;147:61-4.

\section{Justice versus equity for haemophiliacs with AIDS}

SIR, - Ms Clare Dyer's editorial only partially exemplifies the dilemma of haemophiliacs. Certainly, corrective measures for screening out high risk donors and heat treatment of blood products to reduce infection with HIV have been introduced. Patients with haemophilia A, however, are still faced with the lifetime regimen of infusion of 50000-60000 units annually of factor VII concentrate, which, when viewed with knowledge of the immunosuppressive properties of factor VIII ${ }^{23}$ calls for the same responsible attention to be given to HIV contaminated blood products until such suppression is shown to be unimportant.

The importance of immunosuppression induced by factor VIII to predisposition to HIV infection in haemophiliacs is possibly exemplified by the high incidence of AIDS-like immune aberrations in patients who do not have antibodies to HIV, suggesting that such aberrations are attributable to factors other than HIV; the variation in the geographical incidence in AIDS associated haemophilia in the United States ${ }^{5}$ for example, haemophiliacs in New York City, an area with one of the highest number of haemophiliac patients with AIDS, were principal recipients of factor VIII concentrate that was not heat treated and which contained the greatest amount of factor XII contaminant and immunosuppressive activity ${ }^{3}$ and the fact that the cumulative incidence of AIDS in patients with haemophilia $\mathrm{A}$ has been reported to be more than five times higher than in those with haemophilia $\mathrm{B},{ }^{6}$ which may be related to the fact that factor VIII is more highly contaminated with factor XIII than is factor IX (the treatment product used in haemophilia B).

Until there is increased availability and use of recombinant factor VIII preparations or solvent and detergent treated factor VIII concentrates derived from monoclonal antibodies (which appear to be devoid of immunosuppressive properties (E Berntrop et al and A Tagliaferri et al, nineteenth international conference of the World Federation of Haemophilia, Washington, DC, 1990) or until other forms of replacement therapy are developed - for example, gene transfer - identifying possible cofactors for infection with HIV, such as factor VIII induced immunosuppression, and successful intervention would certainly seem to be not only just and equitable for haemophiliac patients, but also of prophylactic importance.

RICHARD J ABLIN

Port Jefferson,

United States

1 Dyer C. Justice versus equity for haemophiliacs with AIDS. $B M 7$ 1990;301:776. (6 October.)

2 Ablin RJ, Bartkus JM, Gonder MJ. Blood product immunosuppression and the acquired immunodeficiency syndrome. Ann Intern Med 1986;104:130.

3 Ablin RJ, Whyard TC, Polgar J, Muszbek L. Delineation and characterization of plasma factor XIII as contributory to immunomodulation by factor VIII concentrates [Abstract]. Thromb Haemostas 1989;62:331.

4 Freedman J, Mazaheri R, Read S, Garvey MB, Teitel J. Humoral and cellular immune abnormalities in adult hemophiliacs followed over a 2-year period. Diagn Clin Immunol 1987.5. $30-40$

5 AIDS Update. Hemophilia exchange, Medical Bulletin No 117 New York: The National Hemophilia Foundation, 1990.

6 Centers for Disease Control. Update: acquired immunodeficiency syndrome (AIDS) in persons with hemophilia. MMWR 1984:33:589-91.

\section{A painful process}

SIR,-The recent anonymous personal view is dismaying.' The anguish suffered by the author at being accused of wrongly diagnosing and managing a case and the cost incurred by the health authority would have been unnecessary if routine necropsy had been the practice. Necropsy numbers are dwindling, sadly, and this important form of medical audit is being ignored.

A NICOL

Leighton Hospital,

Crewe CW' 14 QJ

1 Anonymous. A painful process. BMF 1990;301:1052-3. (3 November.)

\section{Management of intercostal drains}

SIR, - We are sorry to disappoint Minerva, who recently seemed squeamish about intercostal tubes. ${ }^{1}$ The study from Copenhagen published in Thorax ${ }^{2}$ to which Minerva refers described a simple method of treating iatrogenic pneumothoraces when there is no continuing air leak. This is an alternative to repeated chest aspiration. The small teflon catheter employed would be inadequate for treating the commoner spontaneous and traumatic pneumothoraces for two reasons. Firstly, in the presence of a continuing air leak intercostal drains should be connected to suction apparatus (for example, a Vernon Thompson pump) with an underwater seal to ensure complete lung inflation. Secondly, small catheters frequently become blocked with blood clot or fibrin debris. ${ }^{+}$Many patients referred to our thoracic surgical unit with unresolving pneumothoraces have been mismanaged with tiny chest drains that are often in the wrong position. In most cases thoracotomy is avoided by a period of correct management with a tube of adequate bore (in our experience at least 28 Charrière gauge).

Minerva is wrong to imply that all pneumothoraces can be properly treated with the $2 \mathrm{~mm}$ plastic cannula and flutter valve. It may be suitable for the small group of patients described in the Copenhagen study but would result in ineffective treatment of most patients with this life threatening condition.

D R HARRISS T R GRAHAM

Nottingham City Hospital,

Nottingham NG5 1PB

I Anonymous. Views. BMF 1990;301:940. (20 October )

2 Laub M, Milman N, Muller D, Struve-Christensen E. Role of small calibre chest tube drainage for iatrogenic pneumothorax. Thorax 1990;45:748-9.

3 Holden MP. Management of intercostal drainage tubes. In Practice of cardiothoracic surgery. Bristol: John Wright and Sons, 1982:3-6.

4 Treasure T, Murphy JP. Pneumothorax. Surgery 1989;75: $1780-6$

\section{Nobel prizes given for clinical research}

SIR, - Mr Rex Rhein writes that "Transplantation of other organs, such as hearts, lungs, and livers, all depend on the work Dr Murray began when he transplanted the first human kidney from one identical twin to the cotwin in December 1954."

The great contribution that Dr Murray has made to the practice of organ transplantation has to be acknowledged, but I have always believed that the work that was really crucial to organ transplantation was that of Mr Roy Calne, who showed the effects of mercaptopurine in canine renal transplantation, working at the Buckstown Browne Farm of the Royal College of Surgeons of England. The work was first applied clinically in the renal unit of the Royal Free Hospital in 1960 in patients under my care. Indeed, the $B M \mathcal{F}$ published an account of these cases and commented on them in an editorial. ${ }^{23}$

These cases caused a good deal of interest at the time, and Professor Hamburger came over from Paris to discuss the work and gave much encouragement. The discussions reassured Calne that his concept was well founded and encouraged him to proceed in the search for better immunosuppressive drugs. He was given the opportunity of doing this in Boston, and azathioprine was found to be better than mercaptopurine.

Clinical organ transplantation grew in the next decades almost more rapidly than we had thought possible. There will always be much interest in its early days, and I write to record again these events, which I think were of the first importance in its development.

JOHN HOPEWELL

Royal Free Hospital,

London NW3 2QG

1 Rhein R. Nobel prizes for clinical research. BMF 1990;301:894 (20 October.

Hopewell J, Calne RY, Beswick I. Three clinical cases of renal transplantation. BMF 1964;i:411-2.

3 Anonymous. More transplanted kidneys [Editorial]. BMf $1964 ; \mathrm{i}: 386-7$

\section{Correction}

\section{A new new general practice}

An editorial error occurred in this letter by Dr Michael Bourke (27 October, $\mathrm{p}$ 986). The third sentence of the second paragraph should read "Certainly we practised from our homes, and our wives were an integral part of the service" and not our lives as published. 